УДК 004.942:519.6

\title{
Modeling the influence of electron beam energy distribution on quality of radiation processing
}

\author{
V.T. Lazurik ${ }^{1}$, V.M. Lazurik ${ }^{1}$, G. Popov ${ }^{1}$, Z. Zimek ${ }^{2}$ \\ ${ }^{l}$ V.N. Karasin Kharkiv National University Svobody Sq. 4, 61022, Kharkov, Ukraine \\ ${ }^{2}$ Institute of Nuclear Chemistry and Technology Ul. Dorodna 16, 03-195, Warsaw, Poland \\ E-mail:lazurik@hotmail.com
}

\begin{abstract}
The obtained values of most probable energy and practical range have been compared to values calculated according to the formula proposed by the internationally recognized documents. The presented results of the study are focused on the issue of the influence of electron beam energy spread on the depth dose distribution and practical range of electron beam in the irradiated material. The computational experiments have been performed using the Monte-Carlo simulation method for modeling the electron beam energy spectra and depth dose distributions of electrons in aluminum target. Obtained values of most probable energy $\boldsymbol{E}_{p}$ and practical range $\boldsymbol{R}_{p}$ have been compared to the values calculated according to formula proposed by the internationally recognized report. The value of a practical range of electrons $\boldsymbol{R}_{\boldsymbol{p}}$ strongly depends on electron beam energy spread, even in case when value of most probable energy $\boldsymbol{E}_{\boldsymbol{p}}$ of electrons in the beam is unchanged. Results of computer experiments show that in case of a large energy spread, and presence of asymmetry of electron energy distribution, the electrons energy can't be determined properly by empirical formulas included to the international standards.
\end{abstract}

Keywords: Monte-Carlo simulation, computational experiments, modeling of beam energy spread, depth-dose distribution, radiation processing.

Зміни енергетичного розподілу електронного пучка мають певний вплив на техніко-економічні параметри обробки випромінюванням об'ємних полімерних пристроїв. Щоденна відтворюваність розподілу енергії електронів може погіршитися 3 кількох різних причин, таких як погана якість експлуатації, вплив зовнішньої температури на параметри прискорювача, слабка або погана якість компонентів, відповідальних за процес прискорення електронів. Слід також зауважити, що в даний час, розподіл енергії електронного пучка на радіаційно-технологічних лініях, не вимірюється. Тому, проведення досліджень впливу розподілу енергії електронного пучка на розподіл глибинних доз в опроміненому продукті $\epsilon$ актуальною науково-практичною задачею щодо радіаційних технологій. Наведено результати дослідження, присвячені питанню впливу енергетичного розподілу пучка електронів на розподіл глибинних доз і практичного пробігу електронного пучка в опроміненому матеріалі. Отримані значення найбільш ймовірної енергії електронного пучка $\boldsymbol{E}_{\boldsymbol{p}}$ та практичного пробігу електронів $\boldsymbol{R}_{\boldsymbol{p}}$ порівнювали зі значеннями, розрахованими за формулою, запропонованою у міжнародних стандартах. Обчислювальні експерименти виконувалися 3 використанням методу Монте-Карло при моделюванні спектрів електронного пучка та глибинних розподілів доз електронів в алюмінієвих мішенях. Значення практичного пробігу електронів $\boldsymbol{R}_{\boldsymbol{p}}$ сильно залежить від енергетичного розподілу електронного пучка навіть у випадку, коли значення найбільш ймовірної енергії $\boldsymbol{E}_{\boldsymbol{p}}$ електронів в пучку незмінно. Проведена серія комп'ютерних експериментів 3 виявлення впливу асиметрії енергетичного розподілу електронного пучка на розподіл глибинних доз. Результати комп'ютерних експериментів показують, що в разі великого розкиду енергії електронів в пучку та наявності асиметрії в розподілі енергії електронів, стандартні характеристики енергія електронів не можуть бути визначені за допомогою емпіричних співвідношень, представлених в міжнародних стандартах.

Ключові слова: моделювання за методом Монте-Карло, обчислювальні експерименти, моделювання розподілу енергії пучка, розподіл глибинних доз, обробка радіацією.

Полученные значения наиболее вероятной энергии электронов в пучке и практического пробега электронов были сопоставлены с значениями, рассчитанными по формулам, предложенным в международных стандартах. Представлены результаты исследований влияния разброса энергии электронного пучка на распределение глубинной дозы и величины практического пробега электронов в облучаемом материале. Вычислительные эксперименты по моделированию энергетических спектров электронного пучка и распределений дозы электронов по глубине в алюминиевой мишени проводились с использованием метода Монте-Карло. Полученные значения наиболее вероятной энергии $\boldsymbol{E}_{\boldsymbol{p}}$ электронов и практического пробега электронов $\boldsymbol{R}_{\boldsymbol{p}}$ сопоставлены с значениями, рассчитанными по формулам предложенным в международных стандартах. Значение практического пробега электронов $\boldsymbol{R}_{p}$ сильно зависит от разброса энергии электронного пучка, даже в том случае, когда значение наиболее вероятной энергии $\boldsymbol{E}_{p}$ электронов в пучке не изменяется. Результаты компьютерных экспериментов показывают, что в случае большого разброса энергии электронов в пучке и наличия асимметрии в распределении энергии электронов, стандартные характеристики энергия электронов не могут быть определены с помощью эмпирических соотношений, представленных в международных стандартах.

Ключевые слова: моделирование методом Монте-Карло, вычислительные эксперименты, моделирование распределений энергии пучка, распределение дозы по глубине, обработка излучением.

\section{Introduction}

Electron beam energy spread variation may have some influence on technical and economical parameters of radiation processing of bulk polymer devices. High energy electron accelerators powered 
by magnetron type of RF source are frequently used in radiation sterilization process [1]. Such device implementation in accelerator may lead to relatively high instability of electron energy and electron energy spread [2]. As an example, Fig.1 shows spectra of electrons in electron beam accelerator in Warsaw, Poland [3].

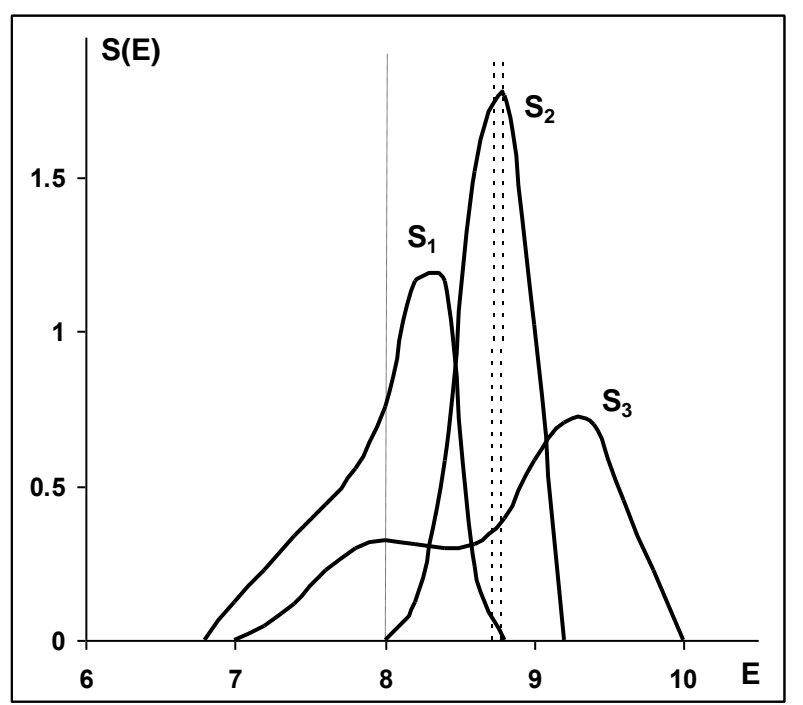

Fig. 1. Spectra of electrons $S(E)$ for different accelerator parameters $\left(S_{1}-\right.$ magnetron $R F$ source average current: $600 \mathrm{~mA}$; pulse current of electron gun: $400 \mathrm{~mA}$, and respectively: $S_{2}-700 \mathrm{~mA} ; 500 \mathrm{~mA}, \mathrm{~S}_{3}-550 \mathrm{~mA}$; $300 \mathrm{~mA}$ )

Day-to-day reproducibility of electron energy and energy spread may be deteriorated by several different reasons like bad quality exploitation, influence of outside temperature on accelerator parameters, weak or bad quality components responsible for electron accelerating process. It should be also noticed that electron beam energy spread is not currently measured in radiation facilities.

The variation of electron energy spread in sterilization facility was investigated with application of computational method for determination of e-beam energy on the base of two-parametric fitting depth dose distribution curve [4.5]. Method can effectively consider electron energy spread value influence on experimental data obtained by the use of aluminum wedge with a continuous polymer strip of dosimetry film [6]. The total effect corresponds to energy losses in accelerator output window, distance between window and irradiated material surface and initial energy spread of electron beam. The e-beam energy losses due to window and air presence are constant for certain electron energy level and specific geometry of irradiation zone. Those energy losses can be estimated on the base of existing literature data [7]. Therefore initial e-beam energy spread and its variation can be evaluated by processing the depth dose distribution data connected to $\boldsymbol{R}_{p}$ (practical range) measurements by two-parametric fitting method. The practical range $\boldsymbol{R}_{p}$ is defined as the depth where extrapolated straight line plotted through the steepest section of electron depth dose curve meets the depth. It should be noticed that influence of electron energy spread on conditions of radiation processing were investigated experimentally long time ago [2]. The following conclusions were formulated: information about the energy spectrum of electron beam is necessary for proper general description but it is less essential for the given radiation installation. The presence of energy spectrum in electron beam can change intensity of the scanned electron beam, what should be considered by suitable arrangement of a beam scanning device.

Paper objective is related to investigating the influence of e-beam energy spread on the depth dose distribution within an irradiated product. The following investigation methods have been applied:

- Computational experiments with e-beams of different spectra; selection of mathematical models of the e-beam spectra and determining the sets of spectrum for performing the numerical investigations;

- Modeling the depth dose distribution of electron radiation in an aluminum target with Monte-Carlo method based on detailed physical model covered by RT-Office software [8];

- Processing of computer experiments results with standard methods, that is used in the electron radiation dosimetry with techniques of dosimetry wedge; 
- Procedures described in "Radiation dosimetry: electron beams with energies between 1 and 50 MeV" [7, 9];

- Comparison results of the computer experiments to identify the characteristics dose distributions dependency from the model parameters of the e-beam spectra.

\section{Models of the energy spread of electrons used in the numerical investigations}

The depth dose distribution initiated by e-beam with energy spread in aluminum has been investigated. Dose distribution can be described by the formula:

$$
D_{M}(x)=\int_{E \min }^{E \max } S(E) \cdot D_{M}(x, E) d E
$$

Where: $S(E)$ - electron beam energy spectrum,

$D_{M}(x)$ - depth dose distribution of electrons radiation in material $\mathbf{M}$,

$D_{M}(x, E)$ - depth dose distribution in material $\mathbf{M}$ irradiated by monoenergetic electron beam with energy $\mathbf{E}$.

The numerical studies have been performed for which uniform and triangular probabilities of energy distribution have been used to describe the spectrum of electrons. The spectrum of the model with uniform distribution of the electron energy has been defined by two parameters: $\boldsymbol{E}_{\min }$ (minimum) and $\boldsymbol{E}_{\max }$ (maximum) value of the energy of electrons within the beam. The spectrum in the model of the triangular distribution of electron energies has been defined by three parameters: $\boldsymbol{E}_{\min }$ and $\boldsymbol{E}_{\max }$ as in the previous case and $\boldsymbol{E}_{p}$ the most probable value of the electrons energy in the beam. The most probably energy $\boldsymbol{E}_{\boldsymbol{p}}$ is defined as an energy at which electron energy spectrum curve has the maximum. Physical quantities with the stochastic nature, such as the electrons spectrum or the angular distribution of the electrons (the terms of probability theory) have been used for description. For example, when the electron energy in the beam is a random variable, the energy spread of the electrons (the term in physics electron spectrum) describes the density function of the random variable probability. Herewith, the value $\boldsymbol{E}_{p}$ is called the mode of the probability density of a random variable.

The notation $\mathbf{S}\left(\boldsymbol{E}_{\min }, \boldsymbol{E}_{\max }\right)$ has been introduced for describing the model spectra of uniform electron energy distribution. The notation $\mathbf{S}\left(\boldsymbol{E}_{\min }, \boldsymbol{E}_{p}, \boldsymbol{E}_{\max }\right)$ has been applied for the triple parameters, describing the triangle distribution of electron energy spectrum. According to the abovementioned notations, the expression $S(10,10)$ or $S(10,10,10)$ describes a mono-energetic electron beam with energy $10 \mathrm{MeV}$ energy in the model of uniform or triangular electron energy distribution in the beam.

As an example, Fig.2 shows electron spectra for uniform and triangular models of the electron energy distribution in the beam. The dashed curve shows the spectrum of electrons in a symmetrical pattern of the triangular electron energy distribution. Examples of entries symmetric $S(6,8,10)$ and asymmetric $S(6,10,10)$ spectra of electrons in the beam can be noticed.

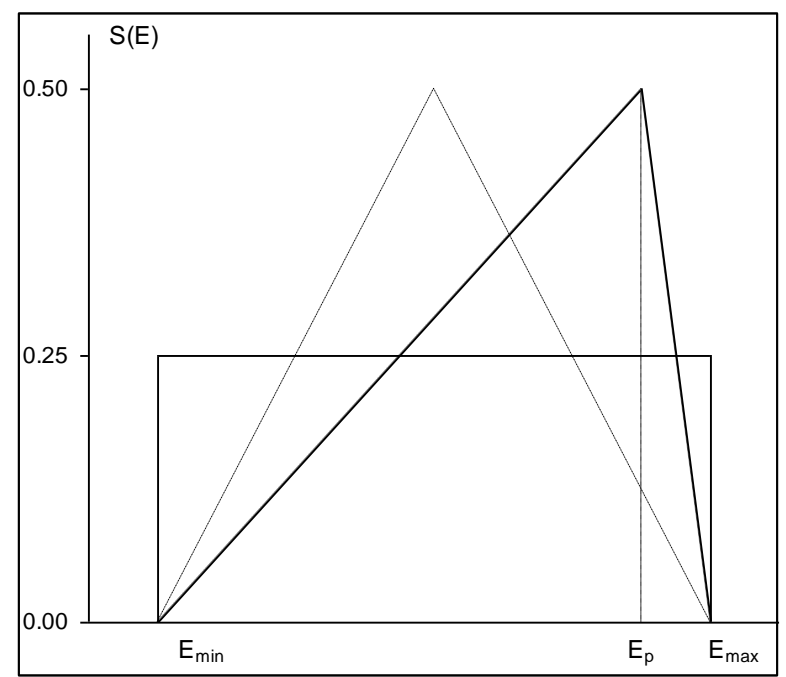

Fig. 2. Models of the electron beam spectrum: uniform and triangular distributions of the electron energy. 
The ratios for the mean value $M(\xi)$ and variance $D^{2}(\xi)$ of the random variable $\xi$ having a uniform probability distribution:

$$
\begin{aligned}
& M(\xi)=\left(E_{\min }+E_{\text {max }}\right) / 2 \\
& D^{2}(\xi)=\left(E_{\max }-E_{\text {min }}\right)^{2} / 12
\end{aligned}
$$

For a triangular probability distribution:

$$
\begin{gathered}
M(\xi)=\left(E_{\text {min }}+E_{p}+E_{\text {max }}\right) / 3 \\
D^{2}(\xi)=\left(\left(E_{\text {min }}^{2}+E_{p}^{2}+E_{\text {max }}^{2}\right)-\left(E_{\text {min }} \cdot E_{p}+E_{p} \cdot E_{\text {max }}+E_{\text {min }} \cdot E_{\text {max }}\right)\right) / 18
\end{gathered}
$$

\section{Computer experiments}

The first series of computer experiments have been performed for studying possibility of calculating the most probable energy of electrons beam $\boldsymbol{E}_{p}$ with using the value of practical range $\boldsymbol{R}_{p}$ of electrons [7, 9]. The value of practical range $\boldsymbol{R}_{p}$ of the electrons has been determined by measuring the depth dose distribution results in a standard dosimetry device (aluminum dosimetry wedge). Determining the value of the most probable electron energy $\boldsymbol{E}_{p}$ in this particular model is out of interest, since the triangle electron energy distribution of the beam defines its value (Fig. 2).

A set of model spectra of electrons has been selected with different energy spread for performing the numerical experiments with the fixed (the same) most probable energy of the electrons in the beam $\boldsymbol{E}_{\boldsymbol{p}}=10 \mathrm{MeV}$. Fig.3 presents examples of the spectra in this set.

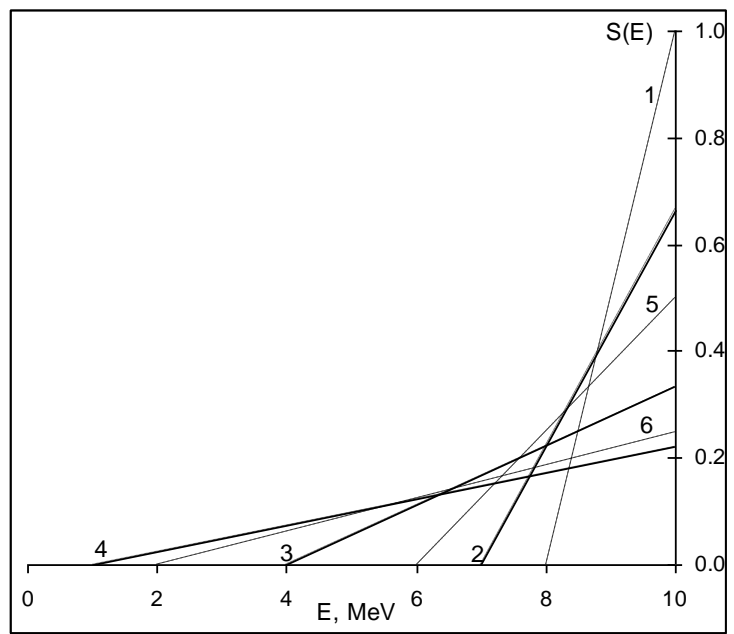

Fig. 3. Electrons spectra in the model of triangular distribution the electrons energy with different energy spread, but with fixed the most probably energy of the electrons in the beam $\left(E_{p}=10 \mathrm{MeV}\right)$

Table 1.Parameters and integral characteristics of the model distributions of electron energy $\boldsymbol{E}$ in beam.

\begin{tabular}{|c|c|c|c|c|}
\hline Name & $\mathrm{S}(\mathrm{a}, \mathrm{b}, \mathrm{c})$ & $M(E)$ & $D^{2}(E)$ & $\sigma(E)$ \\
\hline S0 & $(10,10,10)$ & 10.00 & 0.000 & 0.000 \\
\hline S1 & $(8,10,10)$ & 9.33 & 0.222 & 0.471 \\
\hline S2 & $(7,10,10)$ & 9.00 & 0.500 & 0.707 \\
\hline S3 & $(4,10,10)$ & 8.00 & 2.000 & 1.414 \\
\hline S4 & $(1,10,10)$ & 7.00 & 4.500 & 2.121 \\
\hline S5 & $(6,10,10)$ & 8.67 & 0.889 & 0.943 \\
\hline S6 & $(2,10,10)$ & 7.33 & 3.556 & 1.886 \\
\hline
\end{tabular}

Table 1 show the main integrated characteristics of the model spectra of electrons which have been used for the first series of numerical experiments. The column "Name" contains the symbols spectrum instance, column "S(a, b, c)" model parameters, " $M(E)$ " (mean values), " $D^{2}(E)$ " (dispersion) and " $\sigma(E)$ " (variance and standard deviation) of the electron energy distribution within the beam. 
Calculations of depth dose distributions of electron radiation in an aluminum target have been performed according to Monte Carlo method according to detailed physical model applied at RT-Office software [8]. Calculations have been performed with mono-energetic electrons beam (energy $10 \mathrm{MeV}$ ) and electron beams with different energy spread, which are shown in Fig. 3 and presented in Table 1. Some results calculations of the depth dose distributions of electron radiation are shown in Fig. 4. Irradiation has been performed by mono-energetic electron beam (with energy $10 \mathrm{MeV}$ ) and electron beams with different energy spread (spectra are shown in Fig. 3 with solid lines marked: 2, 3 and 4).

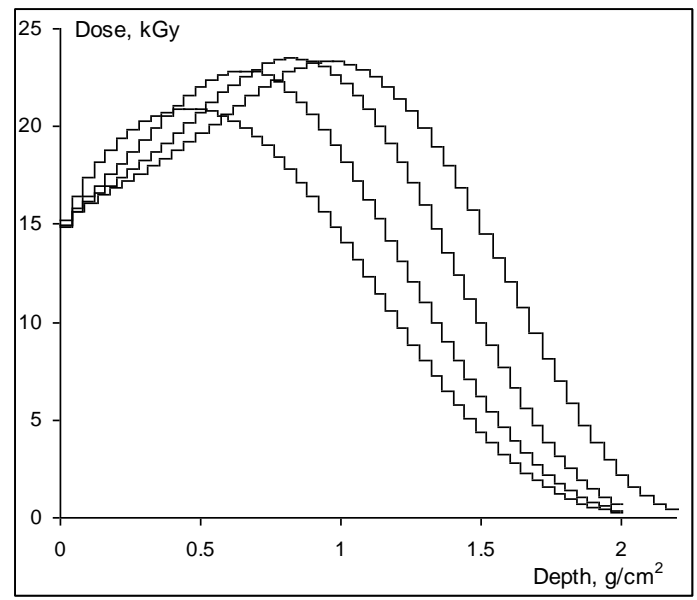

Fig. 4.Depth dose distributions in aluminum target irradiated by electron beams with different energy spread.

\section{Results calculation and discussion}

Fig.5 shows smooth curves, drawn through the middle of the histogram cell, shown at Fig. 4. The points (open circles) in the middle of the histogram have been selected for the calculation of the practical range $\boldsymbol{R}_{p}$ of the electrons with the linear approximation method (lines passing through the points). As it can be seen at Fig. 5 the depth dose distributions are strongly modified for different value of by electrons energy spread within the beam. To assess the possibility of determination the most probable energy of electrons $\boldsymbol{E}_{\boldsymbol{p}}$ on the basis of depth dose distribution data in the standard material (aluminum), the value of practical range $\boldsymbol{R}_{p}$ of electrons and the depth of half dose reduction $\boldsymbol{R}_{50}$ have been identified.

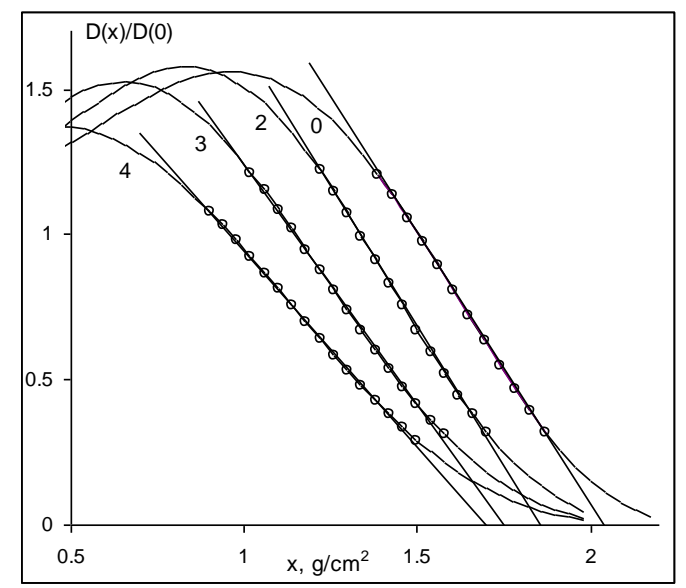

Fig. 5. Procedures for determination the practical range $R_{p}$ of the electrons for normalized depth dose distributions curves.

Fig.5 illustrates procedures for determining the practical range $R_{p}$ of electrons and adequately the depth of half dose reduction $R_{50}$ for normalized depth dose distributions. The data are related to the energy spread distributions presented above and illustrate the change of practical range $R_{p}$ for selected cases of the electron beam energy spread value. It can be seen from Fig. 5, that value of practical range $R_{p}$ of electrons strongly depends on the energy spread of electron beam. It contradicts the statement, presented in the international reports [7,9], about a direct correlation between the value of the most 
probable energy of electrons $E_{p}$ and the value of practical range of electrons $R_{p}$. The value of most probable energy $E_{p}$ for all spectra presented in Fig. 3 is $10 \mathrm{MeV}$, but the values of practical range $R_{p}$ of electrons are significantly different. In respect to that there is a principal question: for which case of the energy spread the formulas are correct. This question is related to empirical relationships of electron radiation dosimetry performed by using the aluminum wedge method:

$$
\begin{aligned}
& E_{p}^{*}=5.09 \cdot R_{p}+0.2 \\
& E_{A v}^{*}=6.2 \cdot R_{50}
\end{aligned}
$$

The results of calculation values of practical range $R_{p}$ of electrons and depth of half-dose reduction $R_{50}$ in aluminum irradiated by electron beams of various spectra are shown in Table 2 . The values of most probably energy $\boldsymbol{E}_{p}^{*}$ and average electron beam energy $E_{A v}^{*}$ have been calculated according to the formulas (6) and (7) respectively.

Table 2. Practical range $\boldsymbol{R}_{p}$ of electrons and depth of the half-dose reduction $\boldsymbol{R}_{50}$ in aluminum irradiated by electron beams with different spectra (energy in $[\mathrm{MeV}]$, ranges in $[\mathrm{cm}]$ ). $\boldsymbol{E}_{p}=\mathbf{1 0 M e V}$.

\begin{tabular}{|c|c|c|c|c|c|}
\hline & $M(E)$ & $R_{p}$ & $R_{50}$ & $E_{p}^{*}$ & $E_{A v}^{*}$ \\
\hline S0 & 10.00 & 2.01 & 1.61 & 10.46 & 9.98 \\
\hline S1 & 9.33 & 1.89 & 1.50 & 9.82 & 9.3 \\
\hline S2 & 9.00 & 1.83 & 1.44 & 9.49 & 8.93 \\
\hline S3 & 8.00 & 1.73 & 1.28 & 9.02 & 7.94 \\
\hline S4 & 7.00 & 1.68 & 1.18 & 8.77 & 7.32 \\
\hline S5 & 8.67 & 1.78 & 1.38 & 9.28 & 8.56 \\
\hline S6 & 7.33 & 1.69 & 1.22 & 8.78 & 7.56 \\
\hline
\end{tabular}

Comparison of the most probable energy of electrons $E_{p}$, for model distributions of electrons energy $E$ within the beam, with those obtained on basis of the standard depth dose distribution processing procedures values $E_{p}^{*}$ leads to the conclusion, that for asymmetric electron beam spectra, the recommendations presented in [7,9] may not be correct. Comparison of the mean energy of electrons $M(E)$, for the model of electron energy $E$ distribution within the beam, with those obtained on the basis of the standard depth dose distribution processing procedure, reveals that values of the average energy of electrons in the beam $E_{A \nu}^{*}$ shows their correlation, even for large values of the relative standard deviations of the energy of electrons.

The conclusion formulated on the base of results obtained from series of computer experiments, allows supposing that development of scientific bases and formation the recommendations on dosimetry of electron radiation in the international reports have been performed using the model of energy distributions of electrons with a small asymmetry. The high-power electron beams in practice have widely and significantly asymmetrical energy distribution of electrons. Therefore first series of computer experiments have been performed with the maximum asymmetric model distribution of electron energy in the beam.

The second series of computer experiments has been devoted to study the influence of asymmetry of electron beam energy spread on the depth dose distributions. At the same time, it has been considered that the main changes in depth dose distribution are associated with change the value of average energy of electrons within the beam having an energy spread.

Fig. 6 shows an example of a set of model spectra of electrons with a fixed value of the average energy $M(E)=8 \mathrm{MeV}$, but different with symmetry (curves 1 and 2) and asymmetric (curve 3) spread of energy relative to the average energy of the electrons.

Table 3 presents the main integrated characteristics of the model spectra of electrons that have been used for second series of numerical experiments. It contains the integral characteristics of electron spectra which correspond to the description given in Table 1. 


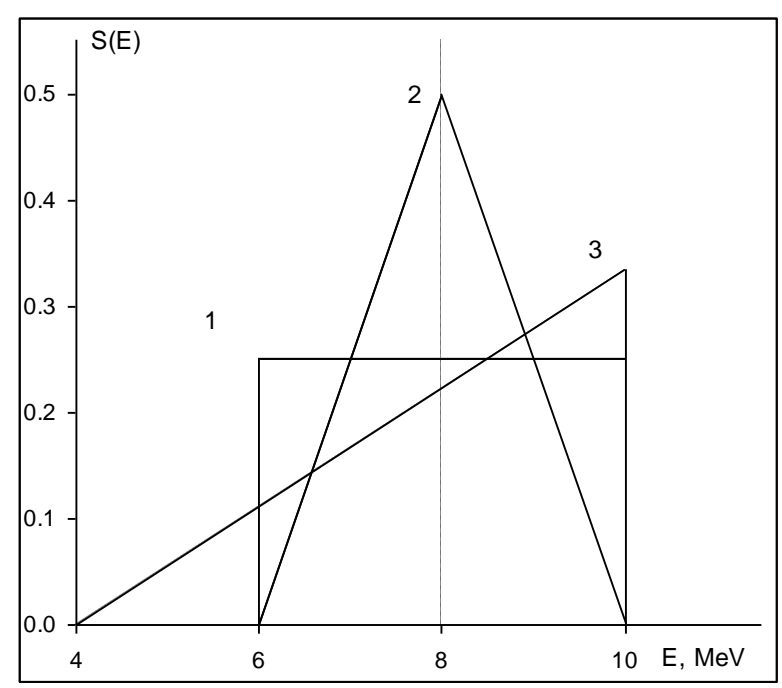

Fig. 6. The spectra of the electron beams with an average energy $M(E)=8 \mathrm{MeV}$. Curves 1 and 2 are symmetric; curve 3 is asymmetric (energy spread of electrons, regarding average value of the electron energy).

Table 3. Parameters and integral characteristics of the model of the electron energy distribution in the beam.

\begin{tabular}{|c|c|c|c|c|}
\hline Name & $\mathrm{S}(\mathrm{a}, \mathrm{b}, \mathrm{c})$ & $M(E)$ & $D^{2}(E)$ & $\sigma(E)$ \\
\hline S7 & $(9,9)$ & 9.00 & 0.000 & 0.000 \\
\hline S2 & $(7,10,10)$ & 9.00 & 0.500 & 0.707 \\
\hline S8 & $(8,9,10)$ & 9.00 & 0.167 & 0.408 \\
\hline S9 & $(8,10)$ & 9.00 & 0.333 & 0.577 \\
\hline S10 & $(8,8)$ & 8.00 & 0.000 & 0.000 \\
\hline S3 & $(4,10,10)$ & 8.00 & 2.000 & 1.414 \\
\hline S11 & $(6,8,10)$ & 8.00 & 0.667 & 0.816 \\
\hline S12 & $(6,10)$ & 8.00 & 1.333 & 1.155 \\
\hline S13 & $(7,7)$ & 7.00 & 0.000 & 0.000 \\
\hline S4 & $(1,10,10)$ & 7.00 & 4.500 & 2.121 \\
\hline S14 & $(4,7,10)$ & 7.00 & 1.5 & 1.225 \\
\hline S15 & $(4,10)$ & 7.00 & 3 & 1.732 \\
\hline
\end{tabular}

The calculations of depth dose distributions after aluminum target electron irradiation have been held by Monte Carlo method with application a detailed physical model of RT-Office software [8]. The calculations have been performed with assumptions related to electron beams with different energy spread. The electron beam parameters are presented in Table 3. Calculations results of depth dose distributions of electron radiation in an $\mathrm{Al}$ target have been grouped by value of the average energy of electrons in the beam $M(E)$. They are shown in Fig. 7.

The values $D_{M}(x)$ of the depth dose distribution of electron radiation are normalized to maximum dose $D_{\max }$ in the target. The dashed curves are marked as the depth dose distribution in target irradiated by mono-energetic electron beam (S7, S10, S13).

As it can be seen from Fig. 7, the depth distribution of electron radiation dose depends on dispersion and asymmetry of the electron beam energy distribution. The results of calculating the values practical range $R_{p}$ of electrons and the depth of half-dose reduction $R_{50}$ in aluminum for the second series of computer experiments are given in Table 4 . The practical range $R_{p}$ of electrons and the depth of half dose reduction $R_{50}$ have been calculated according to the formulas (6) and (7). The values of the most probable electron energy $E_{p}^{*}$ and average energy of electrons within the beam $E_{A v}^{*}$ are presented in Table 4. 

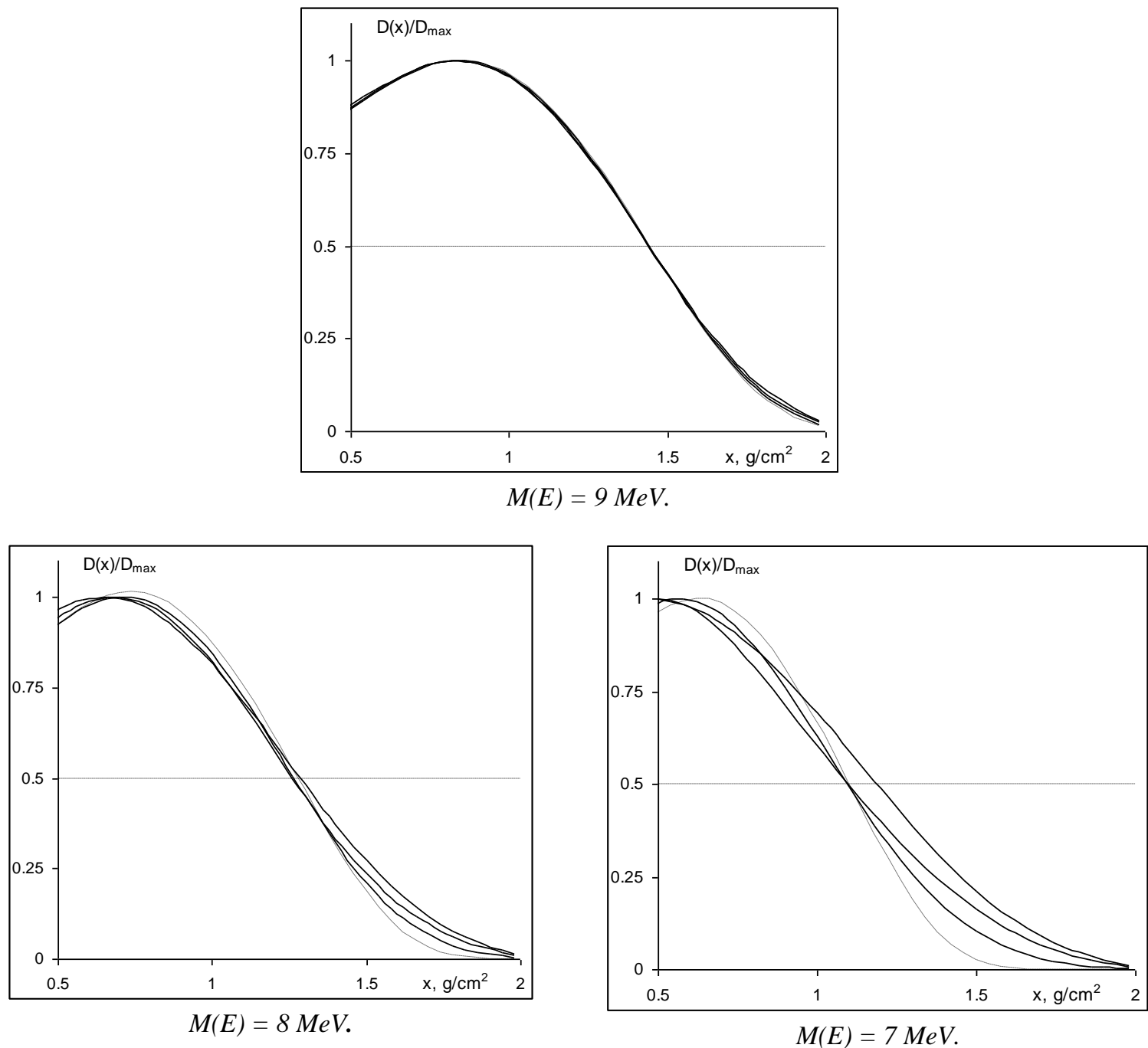

Fig. 7. Depth dose distribution of electron radiation in the aluminum target irradiated by electron beams with different energy spread and average energy of the electrons $M(E)$

Table 4. Practical range $R_{p}$ of electrons and depth of the half-dose reduction $R_{50}$ in aluminum irradiated by electron beams with different spectra (energy in [MeV], ranges in $\mathrm{Al}$ in $[\mathrm{cm}]$ ).

\begin{tabular}{|c|c|c|c|c|c|c|}
\hline Name & $E_{p}$ & $M(E)$ & $R_{p}$ & $R_{50}$ & $E_{p}^{*}$ & $E_{A v}^{*}$ \\
\hline S7 & 9.00 & 9.00 & 1.81 & 1.44 & 9.42 & 8.93 \\
\hline S2 & 10.00 & 9.00 & 1.83 & 1.44 & 9.49 & 8.93 \\
\hline S8 & 9.00 & 9.00 & 1.81 & 1.44 & 9.44 & 8.93 \\
\hline S9 & -- & 9.00 & 1.82 & 1.44 & 9.44 & 8.93 \\
\hline S10 & 8.00 & 8.00 & 1.61 & 1.26 & 8.38 & 7.81 \\
\hline S3 & 10.00 & 8.00 & 1.73 & 1.28 & 9.02 & 7.94 \\
\hline S11 & 8.00 & 8.00 & 1.63 & 1.29 & 8.51 & 8.00 \\
\hline S12 & -- & 8.00 & 1.67 & 1.26 & 8.72 & 7.81 \\
\hline S13 & 7.00 & 7.00 & 1.39 & 1.10 & 7.28 & 6.82 \\
\hline S4 & 10.00 & 7.00 & 1.68 & 1.18 & 8.77 & 7.32 \\
\hline S14 & 7.00 & 7.00 & 1.48 & 1.09 & 7.71 & 6.76 \\
\hline S15 & -- & 7.00 & 1.59 & 1.09 & 8.27 & 6.76 \\
\hline
\end{tabular}

The assumption of symmetry of the electron energy distribution allows establishing a correlation between the average energy of the electrons in the beam $\boldsymbol{E}_{\boldsymbol{A} v}$ and a depth of half dose reduction $\boldsymbol{R}_{50}$. The value $\boldsymbol{R}_{50}$ corresponds to the point of intersection of the curves of depth depending on the dose with the 
dashed line shown in the figures. In the case of a large energy spread the presence of asymmetry in electron energy distribution does not allow determining the average energy of the electrons in the beam, using empirical formulas recommended in the international standards [7, 9]. To assess accuracy of empirical dependence of the average energy $E_{A \nu}^{*}$ of electron beam calculated with the half depth dose reduction $R_{50}$ range (equation (7)), one should take into account results of calculating the average energy $E_{A v}$ of electron beam with approximation proposed in [4]:

$$
R_{50}\left(E_{A v}\right)=0.1691 \cdot E_{A v}-0.0965 \text {. }
$$

Comparing the data within the columns " $E_{A v}^{*}$ " and " $E_{A v}$ " allows estimating the errors of empirical dependences of the average energy of electron beam on the depth of half dose reduction. The value $<4 \%$ can be achieved on the basis of estimates of the error of empirical formula which can be seen in Table 5 .

Table 5.Evaluation of the results of errors according to computer experiments.

\begin{tabular}{|c|c|c|c|c|c|}
\hline Name & $M(E)$ & $E_{A v}^{*}$ & $E_{A v}$ & $\Delta_{F}$ & $\Delta_{E}$ \\
\hline S7 & 9.00 & 8.93 & 9.09 & 0.16 & 0.07 \\
\hline S2 & 9.00 & 8.93 & 9.09 & 0.16 & 0.07 \\
\hline S8 & 9.00 & 8.93 & 9.09 & 0.16 & 0.07 \\
\hline S9 & 9.00 & 8.93 & 9.09 & 0.16 & 0.07 \\
\hline S10 & 8.00 & 7.81 & 8.02 & 0.21 & 0.19 \\
\hline S3 & 8.00 & 7.94 & 8.14 & 0.2 & 0.06 \\
\hline S11 & 8.00 & 8.00 & 8.20 & 0.2 & 0 \\
\hline S12 & 8.00 & 7.81 & 8.02 & 0.21 & 0.19 \\
\hline S13 & 7.00 & 6.82 & 7.08 & 0.26 & 0.18 \\
\hline S4 & 7.00 & 7.32 & 7.55 & 0.23 & -0.32 \\
\hline S14 & 7.00 & 6.76 & 7.02 & 0.26 & 0.24 \\
\hline S15 & 7.00 & 6.76 & 7.02 & 0.26 & 0.24 \\
\hline
\end{tabular}

$\Delta_{F}$-distinction values of energy calculated with different empirical formulas $\Delta_{F}=E_{A v}-E_{A v}^{*}$, $\Delta_{E}$-distinction values of energy calculated with standard empirical formula from the average value of energy in the $\operatorname{spectrum} \Delta_{E}=M(E)-E_{A v}^{*}$,

\section{Conclusions}

The depth dose distribution can vary greatly with changing the energy spread of electrons within a beam. The value of a practical range $R_{p}$ of electrons strongly depends on the energy spread of the electron beam, even in the cases when the value of the most probable energy of the electrons in the beam $E_{p}$ is unchanged. This contradiction result of computer experiments was revealed on the base of the international technical reports for standards of electron radiation dosimetry based on measurements of depth dose distributions with wedge or stack. The possible explanation of arisen contradictions is proposed according to the results of numerical studies in the first part of this paper. We suggest that the conclusions presented in [7] are based on the investigated cases where electron beams are characterized by a small asymmetric energy spread distribution.

The series of computer experiments on identifying the influence of energy spread asymmetry of electron beam on the depth dose distribution have been planned and performed. The results of computer experiments show that in the case of a large energy spread, the presence of asymmetry in electron energy distribution does not allow determining properly the energy of electrons by empirical formulas recommended in the technical reports [7, 9]. 


\section{REFERENCES}

1. Z. Zimek, L.Waliś, A.G.Chmielewski, "EB Industrial facility for radiation sterilization of medical devices". Radiat. Phys. Chem, vol.42, pp. 571-572. 1993.

2. Z.P. Zagórski, "Dependence of dept-dose distribution on the energy spectrum of 5 to $13 \mathrm{MeV}$ electron beams". Radiat. Phys. Chem, vol. 22, No 3-5. pp. 409-418, 1983.

3. V.T. Lazurik, V.M. Lazurik, G. Popov, Z. Zimek, "Determination of electron beam parameters on radiation-technological facility for simulation of radiation processing". East European Journal of Physics, vol.1, No. 3. pp. 74-78, 2014.

4. V.M. Lazurik, V.T. Lazurik, G. Popov, Z. Zimek, "Two-parametric model of electron beam in computational dosimetry for radiation processing". Radiat. Phys. Chem, vol. 124, pp. 230-234, 2016.

5. V.T. Lazurik, V.M. Lazurik, G. Popov, Z. Zimek, "Method of Dosimetry Based on a TwoParametric Model of Electrons Beam for Radiation Processing", Problems of Atomic Science and Technology, №6 (112), pp.137-141, 2017.

6. L. Pages, E. Bertel, H. Joffre, L. Sklavenitis, "Pertesd'energie, parcours et rendement de freinage pour less electrons de $10 \mathrm{keV}$ à $100 \mathrm{MeV}$ dans les elements simples et quelques composes chimiques", Rapport CEA-R-3942, 1970.

7. Radiation dosimetry: electron beams with energies between 1 and $50 \mathrm{MeV}$, ICRU REP. 35, 1984. $160 \mathrm{p}$.

8. V.M. Lazurik, V.T. Lazurik, G. Popov, Yu. Rogov, Z. Zimek, Information System and Software for Quality Control of Radiation Processing. Book, Warsaw, Poland: IAEA Collaborating Center for Radiation Processing and Industrial Dosimetry, 2011.

9. ISO/ASTM Standard 51649, Practice for dosimetry in an e-beam facility for radiation processing at energies between $300 \mathrm{keV}$ and $25 \mathrm{MeV}$, Annual Book of ASTM Standards, Vol. 12.02, 2005.

\section{ЛІТЕРАТУРА}

1. Zimek Z., Waliś L., Chmielewski A.G. 1993. EB Industrial facility for radiation sterilization of medical devices. Radiat. Phys. Chem. 1993. Vol.42. P. 571-572/

2. Zagórski Z.P. Dependence of dept-dose distribution on the energy spectrum of 5 to $13 \mathrm{MeV}$ electron beams. Radiat. Phys. Chem. 1983. Vol. 22, No 3-5. P. 409-418.

3. Lazurik V.T., Lazurik V.M., Popov G., Zimek Z. Determination of electron beam parameters on radiation-technological facility for simulation of radiation processing". East European Journal of Physics. 2014. vol.1, No. 3. P. 74-78.

4. Lazurik V.M., Lazurik V.T., Popov G., Zimek Z. Two-parametric model of electron beam in computational dosimetry for radiation processing. .Radiat. Phys. Chem. 2016. Vol. 124, P.230-234.

5. Lazurik V.T., Lazurik V.M., Popov G., Zimek Z. Method of Dosimetry Based on a Two-Parametric Model of Electrons Beam for Radiation Processing. Problems of Atomic Science and Technology. 2017. №6 (112). P.137-141.

6. Pages L., Bertel E., Joffre H., Sklavenitis L. Pertesd'energie, parcours et rendement de freinage pour less electrons de $10 \mathrm{keV}$ à $100 \mathrm{MeV}$ dans les elements simples et quelques composes chimiques. Rapport CEA-R-3942, 1970.

7. ICRU REP, 35. Radiation dosimetry: electron beams with energies between 1 and $50 \mathrm{MeV}$. 1984, $160 \mathrm{p}$.

8. Information System and Software for Quality Control of Radiation Processing: book. / Lazurik V.M., Lazurik V.T., Popov G., Rogov Yu., Zimek Z. Warsaw, Poland: IAEA Collaborating Center for Radiation Processing and Industrial Dosimetry. 2011. 220 p.

9. ISO/ASTM Standard 51649. Practice for dosimetry in an e-beam facility for radiation processing at energies between $300 \mathrm{keV}$ and $25 \mathrm{MeV}$. Annual Book of ASTM Standards. Vol. 12.02 (2005).

Lazurik Valentine T. - doctor of physical and mathematical sciences, professor; Dean of Computer science faculty; V.N. Karazin Kharkiv National University, Ukraine, 61022, Kharkiv, Svobody Sq., 4; e-mail:vtlazurik@karazin.ua; ORCID: 0000-0002-8319-0764. 
Lazurik Valentina M. - Senior programmer, senior lecturer of Computer science faculty; V.N. Karazin Kharkiv National University, Ukraine, 61022, Kharkiv, Svobody Sq.,4; e-mail: lazurik@ hotmail.com; ORCID: 0000-0002-3340-9780.

Popov Gennadiy F. -Leader researcher, senior lecturer of Computer science faculty; V.N. Karazin Kharkiv National University, Ukraine, 61022, Kharkiv, SvobodySq., 4; e-mail:popov_gen@yahoo.com; ORCID: 0000-0002-4794-8427.

Zimek Zbigniew - Head of Centre for radiation chemistry and technology; Institute of nuclear chemistry and technology, Poland, 03-195, Warsaw, Ul.Dorodna 16, e-mail: Z.Zimek@ichtj.waw.pl; ORCID: 0000-0002-8653-5609.

Лазурик Валентин Т. - доктор физико-математических наук, профессор; декан факультета компьютерных наук; Харьковский национальный университет имени В.Н. Каразина, Украина, 61022, Харьков, пл. Свободы, 4; e-mail:vtlazurik@karazin.ua; ORCID: 0000-0002-8319-0764.

Лазурик Валентина М. - ведущий программист, старший преподаватель факультета компьютерных наук; Харьковский национальный университет имени В.Н. Каразина, Украина, 61022, Харьков, пл. Свободы,, 4; e-mail: lazurik@hotmail.com; ORCID: 0000-0002-3340-9780.

Попов Геннадий Ф. - ведущий научный сотрудник, доцент факультета компьютерных наук; Харьковский национальный университет имени В.Н. Каразина, Украина, 61022, Харьков, пл. Cвободbl, 4; e-mail:popov_gen@yahoo.com; ORCID: 0000-0002-4794-8427.

Зимек Збигнев - заведующий центром радиационной химии и технологии; Институт ядерной химии и технологии, Польша, 03-195, Варшава, ул. Дородная 16, e-mail:Z.Zimek@ichtj.waw.pl; ORCID: 0000-0002-8653-5609.

Лазурик Валентин Т. - доктор фізико-математичних наук, професор; декан факультету комп'ютерних наук; Харківський національний університет імені В.Н. Каразіна, Украйна, 61022, Харків, пл. Свободи, 4; ; e-mail: vtlazurik@karazin.ua; ORCID: 0000-0002-8319-0764.

Лазурик Валентина М. - провідний програміст, стариий викладач факультету комп'ютерних наук; Харківський національний університет імені В.Н. Каразіна, Украйна, 61022, Харків, пл. Свободи, 4; e-mail: lazurik@hotmail.com; ORCID: 0000-0002-3340-9780.

Попов Геннадій Ф. - провідний науковий співробітник, доцент факультету комп'ютерних наук; Харківський наиіональний університет імені В.Н. Каразіна, Украйна, 61022, Харків, пл. Свободи, 4; e-mail:popov_gen@yahoo.com; ORCID: 0000-0002-4794-8427.

Зімек Збігнев - завідувач иентром радіаиійної хімії і технології; Інститут ядерної хімії та технології, Польща, 03-195, Варшава, вул. Дорідна 16, , e-mail: Z.Zimek@ichtj.waw.pl;

ORCID: 0000-0002-8653-5609. 